\title{
Population dynamics of mistletoes species on Cassia fistula in Purwodadi Botanic Garden, Indonesia
}

\author{
SOLIKIN \\ Purwodadi Botanic Garden, Research Center for Plant Conservation and Botanic Garden, Indonesian Institute of Sciences. J1. Raya Surabaya-Malang Km \\ 65, Purwodadi, Pasuruan 67163, East Java, Indonesia. Tel.: +62-343-615033, Fax.: +62-343-615033, email: solikin@lipi.go.id; lipisolikin@gmail.com
}

Manuscript received: 26 November 2020. Revision accepted: 5 February 2021.

\begin{abstract}
Solikin. 2021. Population dynamics of mistletoes species on Cassia fistula L. in Purwodadi Botanic Garden, Indonesia. Biodiversitas 22: 1612-1620. Several species of mistletoe are parasitizing and infesting cultivated plants in Purwodadi Botanic Garden, Pasuruan, East Java i.e. Dendrophthoe pentandra (L.) Miq., Macrosolen tetragonus (Blume) Miq., Scurrula atropurpurea (Blume) Danser, Viscum articulatum Burm.f., and Viscum ovalifolium Wall. ex DC. The population of the mistletoes is dynamics affected by genetic and environment. The study aimed to investigate the population dynamics of mistletoe species on Cassia fistula L. in Purwodadi Botanic Garden, Indonesia. Data collection was conducted by direct observation in the garden on the mistletoe species, parasite density, and host prevalence in four block locations and 28 trees of $C$. fistula. Data were analyzed by two-way ANOVA and tested by Least Significantly Difference (LSD) if there was a significant difference in blocks and year. The results showed two species of mistletoe found on $C$. fistula, i.e. D. pentandra and V. articulatum. Parasitic density was significant different and infested host prevalence also different in blocks and years. The highest parasite density per host plant was reached in block III.D in 2015,i.e. $7.00 \pm 2.95$ and $2.28 \pm 0.85$ individuals per plant for D. pentandra and V. articulatum, respectively. The highest infested host prevalence of 100.00 was reached in block III.D in 2015 and XVI.A since 2012.
\end{abstract}

Keywords: Cassia fistula, infestation, mistletoe, population, Purwodadi Botanic Garden

\section{INTRODUCTION}

Mistletoes are perennial and aerial hemiparasitic plants that have evergreen leaves. There were about 1600 species of mistletoes throughout the world (Griebel et al. 2017) except Antarctica (Rubiales et al. 2011). Loranthaceae is the most dominant family and had the most species of mistletoe in tropical zones. The Philippines, New Guinea, and Northern Borneo were diversity centers of the mistletoes in Malesia which had 23 genera and 193 species of the family Loranthaceae (Barlow 1997). The family is also the dominant mistletoe in Java which had 14 genera and 37 species (Backer and van den Brink 1965).

Mistletoes are found parasitizing many tropical tree species as their hosts, such as Dendrophthoe pentandra (L.) Miq. on Dillenia philippinensis, Cassia garrettiana, Ficus fistulosa, and Hydnocarpus sumatranus in Purwodadi Botanic Garden (Solikin 2016). Cassytha filiformis on Melastoma malabathricum, Acmena acuminatissima, Dicranopteris linearis, and Adinandra dumosa in Batam (Solikin 2017). D. pentandra on Annona reticulata, Annona squamosa, and Psidium guajava. in Bangkalan Madura (Solikin 2020a). The mistletoes absorb water and mineral nutrients also access photosynthate from their hosts by their haustoria (Barlow 1997) which sticks and penetrates to stem tissues so that they will influence the growth of their hosts.

Bediako et al. (2013) reported that the parasitization and infestation of mistletoes caused stunted growth, mortality, and reduced yield of Citrus, i.e., 65\%, 55\%, and
95\% respectively in Central Ghana. Lech et al. (2020) reported that European mistletoe (Viscum album) has become an important agent of damage on forest trees in Central Europe causing tree crown defoliation. The mistletoe attacking on teak Clonal Seed Orchard (CSO) caused decreasing fruit yields in many mother trees significantly (Muttaqin et al. 2016).

Mistletoes have an ecologically important function such as increasing faunal and floral diversity (Griebel et al. 2017), as a keystone resource for wildlife (Watson 2016), and improve habitat quality for threatened species or enhancing ecosystem function (Mellado et al. 2016). Some species of the mistletoes have potential as medicinal plants and have been used as medicinal herbs in the world, such as Scurrula atropurpurea Blume (Danser) (Priyanto et al. 2014) and S. ferruginea (Ameer et al. 2015) for anticancer, antimicrobial, antioxidant, and antihypertensive activities (Lim et al. 2016). D. pentandra had antidiabetic activity (Hardiyanti et al. 2018).

The population of the mistletoes is dynamics in Purwodadi Botanic Garden. Solikin (2016) reported that the population of $D$. pentandra in this garden increased during 2006-2013 from 198 individuals in 2006 to 290 individuals in 2013. It is affected by biotic and abiotic factors. Biotic factors such as characteristics and growth of the mistletoes and host plants (Teodoro et al. 2013), competition between parasites (Monica et al. 2017) and or hosts (Dlama et al. 2016), also birds as mistletoe dispersers. Whereas abiotic factors such as water, mineral nutrients (Kolodziejek et al. 2013) and light (Luo et al. 2016; Solikin 
2020b). The prediction of future population dynamics is needed for planning and implementing targeted and timely management strategies to control the distribution of the mistletoe population (Watson et al. 2017). Cassia fistula is interested in the study of population dynamics of the mistletoe, since it has been observed since 2005 in Purwodadi Botanic Garden (Solikin 2016). It is often to be a host of mistletoes either growing wild or cultivated in the fields (Solikin 2020b).

Infestation and population of the mistletoes on host plant species are dynamically affected by genetic of the mistletoes, host species, and environments. This study aimed to investigate the population dynamic of mistletoe species on Cassia fistula L. in Purwodadi Botanic Garden, Indonesia between 2012 and 2019.

\section{MATERIALS AND METHODS}

\section{Study area}

The study was conducted in Purwodadi Botanic Garden in 2012, 2014, 2015, 2017, 2018, and 2019, located in Purwodadi Sub-district, Pasuruan District, East Java Province, Indonesia at altitude $300 \mathrm{~m}$ asl. with area 85 ha. Climate data in Purwodadi Botanic Garden during the observation was showed in Table 1. Mistletoes and their hosts ( $C$. fistula) are located in blocks III.D, III.E, XII.F, and XV.A contained 12, 9, 6, and 1 individuals of $C$. fistula, respectively. The average plant distance between the trees of $C$. fistula in block III.D, III.E, and XII.F was $4.5 \mathrm{~m}, 4.5 \mathrm{~m}$, and $4.8 \mathrm{~m}$, respectively.

\section{Procedures}

Data collection was conducted by direct observation in blocks III.D, III.E. XII.F, and XV.A where the mistletoes and $C$. fistula were found. Data recording were consisted of species of the mistletoes, host and parasite number, plant height, and stem diameter in $120 \mathrm{~cm} \mathrm{DBH}$. All of the mistletoes' positions observed were on the outer of the host plant canopies. The mistletoes on the host plants were identified directly in the field to determine their species and referred to Barlow (1997). Binocular was used to observe the mistletoes on branches and twigs.

\section{Data analysis}

Data of the mistletoes and host number collected from the field was used to count infested host prevalence and parasite density. Infested host prevalence (P) shows the proportion of a number of the infected host by mistletoes (I) and total number of hosts (N) (Miller et al. 2018) while parasite density per host shows the proportion of parasite number (individual) and the total number of hosts in a block. Statistical analysis by two-way ANOVA was conducted to determine whether there was a significant difference in mistletoes density during observation in 20122019 and between site blocks. Statistical data analysis used MINITAB 13 program. Least Significantly Difference (LSD) test was conducted if there was a significant difference between the years and blocks.

\section{RESULTS AND DISCUSSION}

\section{Species and distribution of mistletoes}

There were two species of mistletoes found parasitizing C. fistula during 2012-2019, i.e. Dendrophthoe pentandra (L.) Miq. (Loranthaceae) and Viscum articulatum Burm.f. (Santalaceae) (Figure 2). Other mistletoes were parasitizing many plant species in Purwodadi Botanic Garden, Pasuruan East Java such as Macrosolen tetragonus (Blume) Miq., Scurrula atropurpurea (Loranthaceae), and V. ovalifolium Wall. ex DC. (Santalaceae) (Solikin 2016). However, these species have not parasitized C. fistula since 2012 even in 2005 until 2019. Backer and van den Brink (1965) reported 22 species of family Loranthaceae and 2 species of family Santalaceae in East Java, while Barlow (1997) reported 26 species of family Santalaceae and 193 species of Loranthaceae in Malesia. It indicates that some hosts have special compatibility (specificity) to the mistletoes so they are only found parasitized by particular mistletoe species such as $D$. pentandra on $C$. fistula. It also shows that the distribution and dispersal of the mistletoes by birds is aggregated on infested plants and adjacent plants on the same species ( $C$. fistula) in the blocks. Aggregated distribution pattern of the mistletoes on their hosts is very common (Kolodziejek et al. 2013) such as distribution of D. pentandra on $C$. fistula as a host in blocks observed. It is also shown in the field such as in block XII.F that $D$. pentandra only aggregated on $C$. fistula. However, there were other species of trees near $C$. fistula, such as Jacaranda obtusifolia, Spathodea campanulata, Kigelia africana, Ficus religiosa, Aegle marmelos, and Limonia acidissima (Table 2).

Table 1. Climate data in Purwodadi Botanic Garden, East Java, Indonesia during 2012-2019

\begin{tabular}{cccccc}
\hline Year & $\begin{array}{c}\text { Rainfall } \\
(\mathbf{m m} \text { per year) }\end{array}$ & $\begin{array}{c}\text { Rainy day } \\
(\text { days per year) }\end{array}$ & $\begin{array}{c}\text { Relative air humidity } \\
(\mathbf{\%})\end{array}$ & $\begin{array}{c}\text { Min. temperature } \\
\left({ }^{\circ} \mathbf{C}\right)\end{array}$ & $\begin{array}{c}\text { Max. temperature } \\
\left({ }^{\circ} \mathbf{C}\right)\end{array}$ \\
\hline 2012 & 1930 & 155 & 70.61 & 20.70 & 30.70 \\
2014 & 1676 & 157 & 72.66 & 20.30 & 30.68 \\
2015 & 1568 & 141 & 74.64 & 19.89 & 30.28 \\
2016 & 3135 & 162 & 74.45 & 20.27 & 30.29 \\
2017 & 3402 & 193 & 72.45 & 20.45 & 31.32 \\
2018 & 1939 & 143 & 75.07 & 20.62 & 31.66 \\
2019 & 1564 & 115 & 76.71 & 20.70 & 30.70 \\
\hline
\end{tabular}

Note: Climate Station of Purwodadi Botanic Garden (unpublished) 
Birds have an important role in the seeds dispersal of the mistletoes in a given infested plant or to other uninfested plants after perching, excreting, and depositing the mistletoe seeds on the branches twigs. There were specialist and generalist birds that have an important role in the seeds' mistletoe dispersal. The birds from genera Dicaeum such as Dicaeum concolor "flowerpecker" is categorized as specialist mistletoes, whereas yellow-vented bulbul (Pycnonotus xanthopygos) as generalist frugivorous (Luo et al. 2016). Dicaeum sp., P. goavier (trucukan), and $P$. aurigaster (kutilang) as frugivorous birds which were found in the garden also have an important role in the mistletoes seeds dispersal in Purwodadi Botanic Garden (Solikin 2020a, b).

\section{Population dynamics and parasite density of the mistletoes}

The population of the mistletoes on the hosts is varied by year and environment of habitat. parasite density on $C$. fistula is different each year during observation in 2012 2019 (Table 3). The density of $D$. pentandra and $V$. articulatum on C. fistula had increased since 2012 and reached the highest density in 2015 with parasite density 7.00 and 2.28 individuals per plant for $D$. pentandra and $V$. articulatum, respectively. The parasite density of $D$. pentandra in the block locations also differs significantly. The parasite density of the $D$. pentandra in block III.D is higher than the other block locations with parasite density 6.55 and 1.84 individuals per plant for $D$. pentandra and $V$. articulatum, respectively (Table 4). It was caused by the number and infested host prevalence by mistletoes in this block is more than other blocks (Table 5).

The infested host prevalence in block III.D is the highest (100.00) with 12 individuals infested trees (Table 5). Solikin (2020b) reported a significant positive correlation between the parasite number per plant and the infested host number on $C$. fistula. The more the infested hosts by mistletoes and parasite density per plant, the more seeds of mistletoe deposited by birds and increase the mistletoe density in a community. The increasing of seeds deposition will increase the infection and population of mistletoes per host plant. This pattern appears to be a direct consequence of increasing perching, depositing, and the seeds dispersing by birds. The high number and prevalence of infested host will attract birds as dispersers visiting, perching, eating fruit, excreting, and depositing the mistletoes seeds on the host trees in the block III.D more frequent than those in the blocks of IIIE, XII.F, and XV.A.

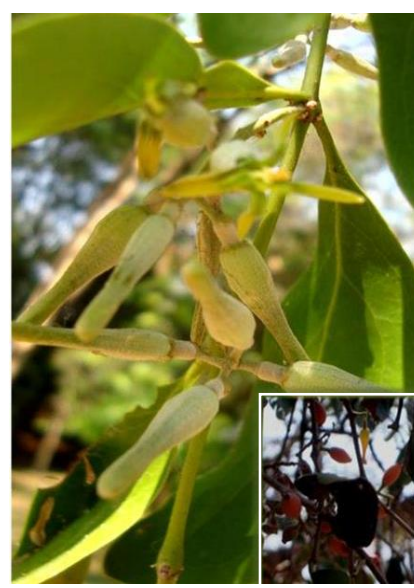

A

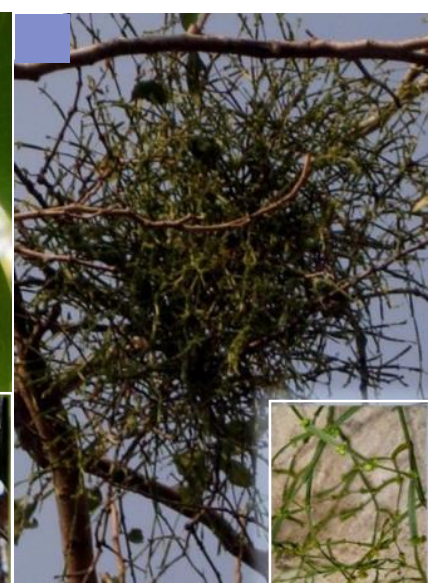

B
Figure 2. The mistletoes on Cassia fistula in Purwodadi Botanic Garden, Pasuruan, Indonesia. A. Dendrophthoe pentandra, B. Viscum articulatum

Table 2. Tree plants species in each block in Purwodadi Botanic Garden, Pasuruan, Indonesia

\begin{tabular}{ll}
\hline Block & Tree species \\
\hline III.D & Cassia fistulat+), Jacaranda obtusifolia, Bougainvillea glabra, Firmiana malayana, Limonia acidissima. Miliusa \\
& horsfieldii, Arenga obtusifolia, Elaeis guineensis, Cocos nucifera, Sallaca zallaca, Areca catechu, Adonidia merrillii, \\
& Pigafetta filiaris, Arenga pinnata, Oncosperma tigillarium, Ptychosperma sp., Sabal palmetto, Nephrosperma \\
& vanhoutteanum, Ptychococcus paradoxus, Syagrus romanzoffiana, Sabal mexicana, Cyrtostachys elegans, Rhopaloblaste \\
& augusta, Latania lontaroies, Saribus rotundifolius, Bentinckia nicobarica, Ptychosperma ambiguum, Acoelorrhaphe \\
& wrightii, Areca montana, Dypsis lutescens, Drymophloeus sp., Heterospathe elata, Orania archboldiana, Rhopaloblaste \\
& ceramica, Hydrastele sp.
\end{tabular}

III.E Cassia fistula ${ }^{++)}$, Jacaranda obtusifolia, Combretum grandiflorum, Metroxylon sagu, Adonidia merrillii, Areca macrocalyx, Pinanga coronata, Actinorhytis calapparia

XII,F Cassia fistula ${ }^{++}$, Jacaranda obtusifolia, Bougainvillea glabra, Aegle marmelos, Limonia acidissima ${ }^{+)}$, Moquilea tomentosa, Ficus religiosa

XV.A Garcinia dulcis ${ }^{+)}$, Bombax ceiba, Ceiba pentandra ${ }^{++}$, Eucalyptus globulus, Madhuca longifolia, Peltophorum pterocarpum, Schleichera oleosa, Adansonia digitata, Cassia fistula ${ }^{++)}$, Cassia garretiana ${ }^{++)}$, Pterocarpus indicus, Pithecellobium dulce ${ }^{++)}$, Crescentia cujete, Phyllanthus emblica, Cananga odorata, Inocarpus fagifer, Mimusops elengi, Firmiana malayana, Alstonia scholaris, Spondias mombin, Hymenaea verrucosa, Citrus lucida ${ }^{+}$ 
Table 3. Parasite density on Cassia fistula during 2012-2019 in Purwodadi Botanic Garden, East Java, Indonesia

\begin{tabular}{lll}
\hline Year & \multicolumn{2}{c}{ Parasite density (individuals per plant) } \\
\cline { 2 - 3 } & D. pentandra & V. articulatum \\
\hline 2012 & $3.11 \pm 1.26^{\mathrm{a}}$ & $1.38 \pm 0.38^{\mathrm{ab}}$ \\
2014 & $4.00 \pm 1.67^{\mathrm{a}}$ & $1.38 \pm 0.38^{\mathrm{ab}}$ \\
2015 & $7.00 \pm 2.95^{\mathrm{b}}$ & $2.28 \pm 0.85^{\mathrm{b}}$ \\
2017 & $4.89 \pm 1.98^{\mathrm{ab}}$ & $1.07 \pm 0.24^{\mathrm{a}}$ \\
2018 & $4.01 \pm 1.67^{\mathrm{a}}$ & $0.91 \pm 0.17^{\mathrm{a}}$ \\
2019 & $1.67 \pm 0.72^{\mathrm{a}}$ & $0.68 \pm 0.11^{\mathrm{a}}$ \\
\hline
\end{tabular}

Note: numbers followed by same alphabetic in the same column were no difference significantly by LSD test at $\alpha=5 \%$.
Table 4. Parasite density on Cassia fistula in four sites location in Purwodadi Botanic Garden, East Java, Indonesia in 2012-2019

\begin{tabular}{lll}
\hline \multirow{2}{*}{ Block } & \multicolumn{2}{l}{ Parasite density (individual per plant) } \\
\cline { 2 - 3 } & D. pentandra & V. articulatum \\
\hline XII. F & $2.05 \pm 1.12^{\mathrm{a}}$ & $0.82 \pm 0.21^{\mathrm{a}}$ \\
III.E & $4.22 \pm 2.09^{\mathrm{ab}}$ & $1.64 \pm 0.52^{\mathrm{a}}$ \\
III.D & $6.55 \pm 3.42^{\mathrm{b}}$ & $1.84 \pm 0.85^{\mathrm{a}}$ \\
XV.A & $3.67 \pm 1.71^{\mathrm{ab}}$ & $0.83 \pm 0.27^{\mathrm{a}}$ \\
\hline
\end{tabular}

Note: numbers followed by same alphabetic in the same column were no difference significantly by LSD test $5 \%$.

Table 5. Infested host prevalence (Cassia fistula) during 2012-2019 in four site blocks in Purwodadi Botanic Garden, East Java, Indonesia

\begin{tabular}{lllllll}
\hline Block & Year & & & & & \\
\cline { 2 - 7 } & $\mathbf{2 0 1 2}$ & $\mathbf{2 0 1 4}$ & $\mathbf{2 0 1 5}$ & $\mathbf{2 0 1 7}$ & $\mathbf{2 0 1 8}$ & $\mathbf{2 0 1 9}$ \\
\hline XVI.A & 100.00 & 100.00 & 100.00 & 100.00 & 100.00 & 100.00 \\
XII.F & 50.00 & 50.00 & 83.33 & 83.33 & 83.33 & 16.67 \\
III.E & 66.67 & 66.67 & 77.78 & 88.89 & 88.89 & 44.44 \\
III.D & 91.67 & 91.67 & 100.00 & 91.67 & 91.67 & 75.00 \\
\hline
\end{tabular}

They can lead to a greater rate of infestation of the mistletoes to the hosts. The average distance between $C$. fistula tree $(4.6 \mathrm{~m})$ may be densely, supporting and icreasing the birds to move, perch, and deposit seeds of mistletoes on the hosts. Aukema and Martinez del Rio (2002) reported that the highest frequency of flight distance of bird Phainopepla which disperses mistletoe Phoradendron californicum among Prosopis velutina to perch was of $1-10 \mathrm{~m}$. The probability of the mistletoes infection increased in the vicinity of infected stems at distances of less than $5 \mathrm{~m}$ (Matula et al. 2015).

Viscum articulatum is a hyperparasite and commonly found as a parasite on D. pentandra, so its life and population will be affected by the population of $D$. pentandra (Solikin 2016; 2020a). Table 6 showed that increasing parasite density of $D$. pentandra in block III.D from 4.33 individuals per plant in 2012 to 12.67 individuals per plant in 2015 was followed by increasing density of $V$. articulatum from 1.58 individuals per plant in 2012 to 1.28 individuals per plant in 2015. The relationship between the parasite density of $D$. pentandra and $V$. articulatum was showed $\mathrm{y}=0.281 \mathrm{x}-0.257$ and $\mathrm{R}^{2}=0.746$ (Figure 3). It means that the parasite density of $V$. articulatum increases linearly and has a positive correlation by increasing population of D.pentandra infesting the host plants. It was also reported and demonstrated by Solikin (2016) that increase of $D$. pentandra in Purwodadi Botanic Garden from 198 individuals per plant in 2006 to 290 individuals per plant in 2013 was followed by increasing of $V$. articulatum from 31 individuals per plant in 2006 to 46 individuals per plant in 2013.

The infestation of mistletoe species on their hosts is dynamics (Griebel et al. 2017). An Increasing population of the mistletoes will be fast in a suitable environment and compatible host. Solikin (2020b) reported that the blocks of III.D, III.E, XII.F, and XV.A have open locations where light can be intercepted fully by outer plant canopies $(>90$ $\%$ ). It is suitable for the growth and development of $D$. pentandra so that its population increased fastly between 2012 and 2015 (Table 7). The highest population growth of $D$. pentandra and $V$. articulatum was reached in 2015 , i.e. $225 \%$ (XIIF) and $333 \%$ (III.D), respectively compared to their population in 2012 (Table 7). The population of $D$. pentandra and $V$. articulatum decreased after 2015 until 2019 (Table 6, Figure 4).

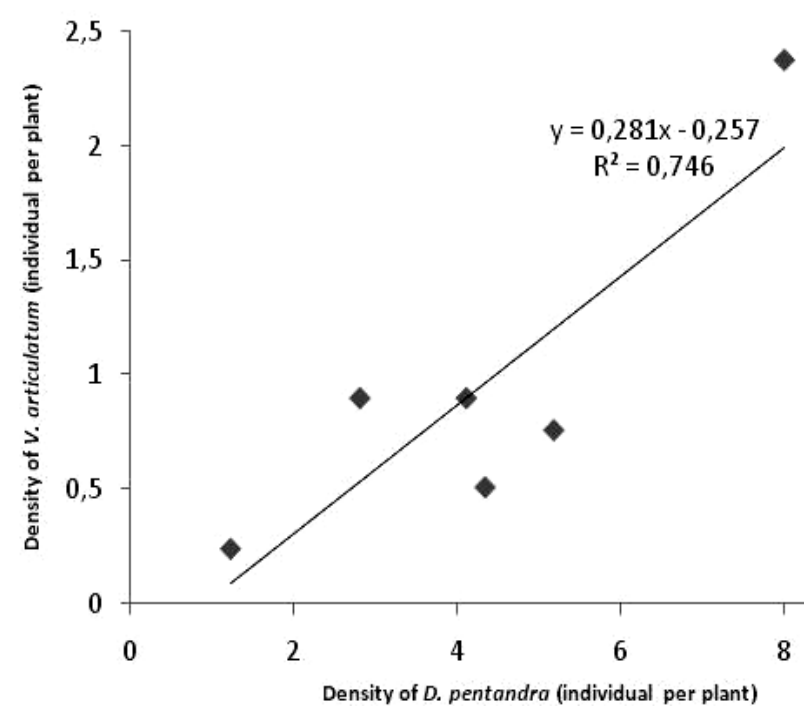

Figure 3. Density relationship between Dendrophthoe pentandra and Viscum articulatum on Cassia fistula in Purwodadi Botanic Garden, East Java, Indonesia 
Table 6. Parasitic density each site block during 2012 - 2019 in Purwodadi Botanic Garden, East Java, Indonesia

\begin{tabular}{|c|c|c|c|c|c|c|c|c|}
\hline \multirow{2}{*}{ Block } & \multirow{2}{*}{ Host number } & \multirow{2}{*}{ Mistletoe species } & \multicolumn{6}{|c|}{ Year } \\
\hline & & & 2012 & 2014 & 2015 & 2017 & 2018 & 2019 \\
\hline XV.A & 1 & Viscum articulatum & 1.00 & 1.00 & 0.00 & 0.00 & 0.00 & 0.00 \\
\hline XII.F & 6 & & 0.17 & 0.17 & 1.00 & 0.33 & 0.17 & 0.00 \\
\hline III.E & 9 & & 0.78 & 0.78 & 2.11 & 1.00 & 0.78 & 0.56 \\
\hline III.D & 12 & & 1.58 & 1.58 & 3.83 & 0.75 & 0.42 & 0.00 \\
\hline XV.A & 1 & Dendrophthoe pentandra & 4 & 4 & 4 & 4 & 3 & 3 \\
\hline XII.F & 6 & & 1.33 & 1.67 & 4.33 & 2.83 & 1.83 & 0.33 \\
\hline III.E & 9 & & 2.78 & 4.33 & 7.00 & 4.89 & 4.44 & 1.89 \\
\hline III.D & 12 & & 4.33 & 6.33 & 12.67 & 7.83 & 6.75 & 1.42 \\
\hline
\end{tabular}

Table 7. Population growth and mortality of Dendrophthoe pentandra and Viscum articulatum on Cassia fistula in four site blocks in Puwodadi Botanic Garden, East Java, Indonesia

\begin{tabular}{lllllllll}
\hline Year & \multicolumn{4}{c}{ D. pentandra (\%) } & \multicolumn{3}{c}{ V. articulatum (\%) } \\
\cline { 2 - 8 } & XII.F & III.E & III.D & XV.A & XII.F & III.E & III.D & XV.A \\
\hline 2012 & 1.33 & 2.78 & 4.33 & 4.00 & 0.25 & 0.83 & 1.63 & 0.25 \\
2014 & 25.31 & 55.88 & 46.27 & 0.00 & 0.00 & 0.00 & 0.00 & 0.00 \\
2015 & 225.81 & 151.80 & 192.53 & 0.00 & 333.33 & 160.00 & 138.46 & 100.00 \\
2017 & 34.57 & 30.16 & 38.32 & 0.00 & 61.42 & 51.36 & 79.60 & 100.00 \\
2018 & 57.66 & 36.51 & 46.85 & 25.00 & 76.85 & 61.60 & 88.19 & 100.00 \\
2019 & 92.30 & 73.02 & 88.85 & 25.00 & 92.28 & 71.84 & 98.93 & 100.00 \\
\hline
\end{tabular}

Note : Data of growth and mortality of the mistletoes was compared to 2015 ; data $\leq 2015$ is growth (increasing) and data $>2015$ is mortality (decreasing).

Resources competition such as water and mineral nutrients between the mistletoes and or host trees will affect the growing population of the mistletoes. Matula et al. (2015) reported that competition between host trees harms mistletoe species occurrence because the trees that outcompete their neighbors usually have better access to resources and more available resources for mistletoe species than the suppress trees. Increasing competition of water, nutrients, and light between the host trees will reduce host plant growth and decrease tree size and lead to a decreasing number of mistletoes infecting trees (Matula et al. 2015). The relatively dense distance $(4.6 \mathrm{~m})$ and dense weeds between the trees of $C$. fistula in blocks of III.D, III.E, and XII.F increase the competition between the trees, affecting the growth and size of the tree, also the mistletoes infection and population in communities. Monica et al. (2017) reported that population growth of Arceuthobium globosum was reduced by competition of resources, such as water and nutrient.

Competition between the parasites and or their hosts for water and nutrients was caused by the parasites absorbing water and nutrients for their growth from their hosts by their haustoria, especially on the branches and twigs where the parasites sticking. Haustoria of the mistletoe penetrate to xylem and phloem tissues. Phloem tapping makes the haustoria easier to access host photosynthate from the hosts while xylem tapping will divert and concentrate nutrients such as nitrogen and phosphorus from the host sap into the mistletoes. Average about $15 \%$ of the total carbon gain of xylem tapping mistletoe is from photosynthate diverted from the xylem stream of the host (Barlow 1997). Penetrating the haustoria into stem transportation tissues (xylem and phloem) will damage these tissues so that they inhibit water, nutrients, and photosynthate transportation to top branches that can reduce and die the distal branches. Solikin (2014) reported that the presence of the mistletoes caused the drying and death of distal branches on $C$. fistula up to to $75.27 \%$. The death of the branches will increase mortality and reduce the parasite density of the mistletoes.

Increasing parasite density of $D$. pentandra and $V$. articulatum during 2012-2015 (Figure 4) may be caused by competition between the parasites and or their hosts on branches and twigs still low and the hosts can support water and nutrients for the plant and parasites' growth. The competition between the parasites and or the hosts in 2015 may be critically competition periods between the parasites and the hosts because after this period, the death of distal branches where the parasites stuck increased and followed by increasing mistletoes death (Figures 4 and 5). The competition between the mistletoes and or their hosts for water and mineral nutrients will be higher caused by a higher increase of parasite density on the hosts and competition between the hosts especially in the dry season where leaves of $C$. fistula fall (deciduous), whereas leaves of the mistletoes are evergreen. Backer and Bakhuizen van den Brink (1965) reported that the mistletoes of the family Loranthaceae in Java did not shun the dry season. 


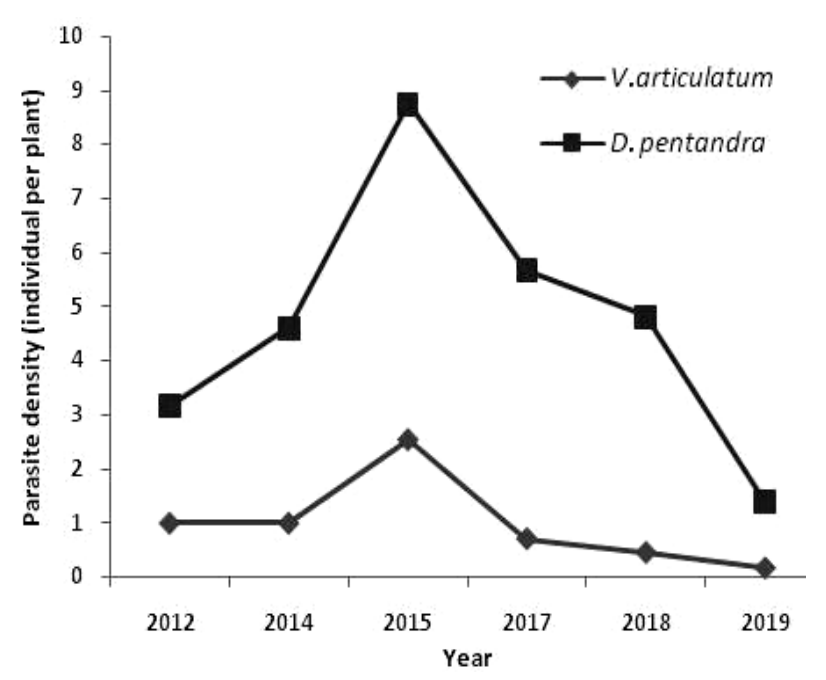

Figure 4. Parasite density of Dendrophthoe pentandra and Viscum articulatum on Cassia fistula in Purwodadi Botanic Garden, East Java, Indonesia during 2012-2019

The occurrence and high density of herbaceous plants around the host plants and relatively dense distance between the trees also increase the competition among the host trees, which indirectly affects the increasing competition, growth, and parasite density of the host tree. The death of the branches and twigs will be followed by the death of the mistletoes on them (Figure 5). The lower rainfall and rainy day in 2015 may affect seriously the death of the mistletoes on the top branches and twigs. It may be correlated to the highest competition between the mistletoes and/or the hosts, which impacts the death of mistletoes and the top branches and twigs of $C$. fistula. The highest death of $D$. pentandra and $V$. articulatum was 92.3 $\%$ (XII.F), and $98.93 \%$ (III.D), respectively in 2019 (Table 7) compared to their population in 2015. However, the death of $V$. articulatum 2015 reached $100 \%$. It was caused by the population number of $V$. articulatum in XV.A only one individual in 2012-2014 and died in 2015.

The parasite density of $D$. pentandra in 2015 (8.75 individuals per plant) may be to become critically population density on $C$. fistula in Purwodadi Botanic Garden. Hence, the growth inhibition and death of the branches and twigs increased continually after this time. The death of the branches and twigs will be followed by the death of parasites on the branches and twigs (Figure 5). The highest mortality of the mistletoes caused the parasite density of $D$. pentandra and V.articulatum on the hosts in block III.D, III.E, and XII.F reached the lowest in 2019 (Table 7). It indicated that the death of branches where the parasites stuck and the parasite species increased fastly after critical parasite population density reached in 2015 . The high rainfall in 2016 and 2017 (Table 1) may have no impact to increase the mistletoes population after 2015 .

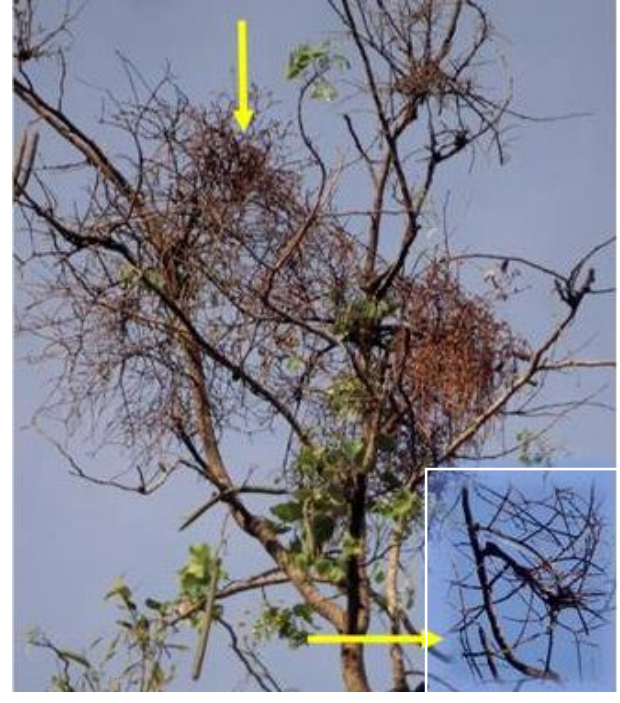

Figure 5. Death of the parasitic plants and branches on Cassia fistula

Parasite density increases and decreases following the increasing or decreasing plant height and the stem diameter (Figure 6). Kolodziejek et al. (2013) reported that the infection density of $V$. album mistletoe on the tall tree was higher than those on middle or small trees. The relationship between the size (diameter and high) of the host and the parasite number can be correlated by birds moving and perching on the tree. The birds as dispersers of mistletoes seeds more like moving and perching on the higher branches so the parasites were more found on the top of the larger or higher trees (Kolodziejek et al. 2013). The diameter of host trees was also another characteristic that influenced mistletoe abundance on host species (Rahmad et al. 2014). Birds that disseminate mistletoes often perched at the tops of the larger trees and depositing more mistletoe seeds in the trees' canopy. The larger and older trees could be more attractive to frugivorous birds for perching and depositing mistletoe seeds on the branches and twigs.

It can be concluded that there were two species of mistletoes parasitized Cassia fistula in Purwodadi Botanic Garden during 2012-2019, i.e. Dendrophthoe pentandra and Viscum articulatum. The parasitization and infestation of the mistletoes on their hosts tend to distribute aggregately in individual or population plants in a community. The parasite density in blocks site tends to increase from 2012 until 2015 and then declining to the lowest in 2019. The block III.D has the highest parasite density of Dendrophthoe pentandra and Viscum articulatum, i.e. $6.55 \pm 3.42$ and $1.84 \pm 0.85$ individuals per plant, respectively. The highest mortality of $D$. pentandra and $V$. articulatum was occurred in 2019, i.e. $92.30 \%$ (XII.F) and $100.00 \%$ (XV.A), respectively. 

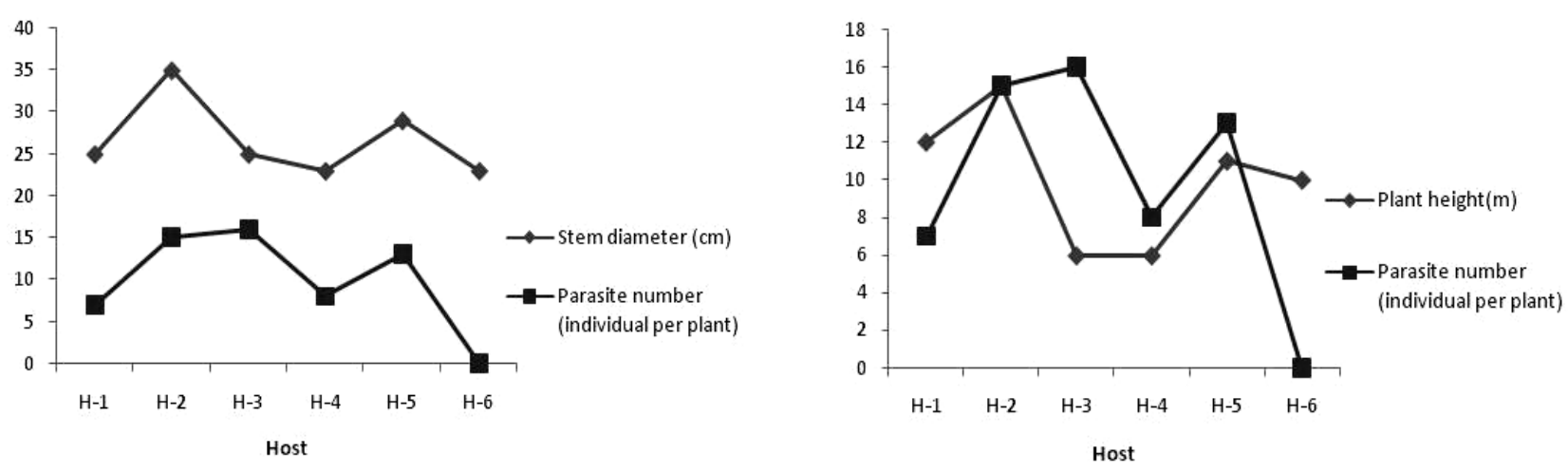

Block XII.F
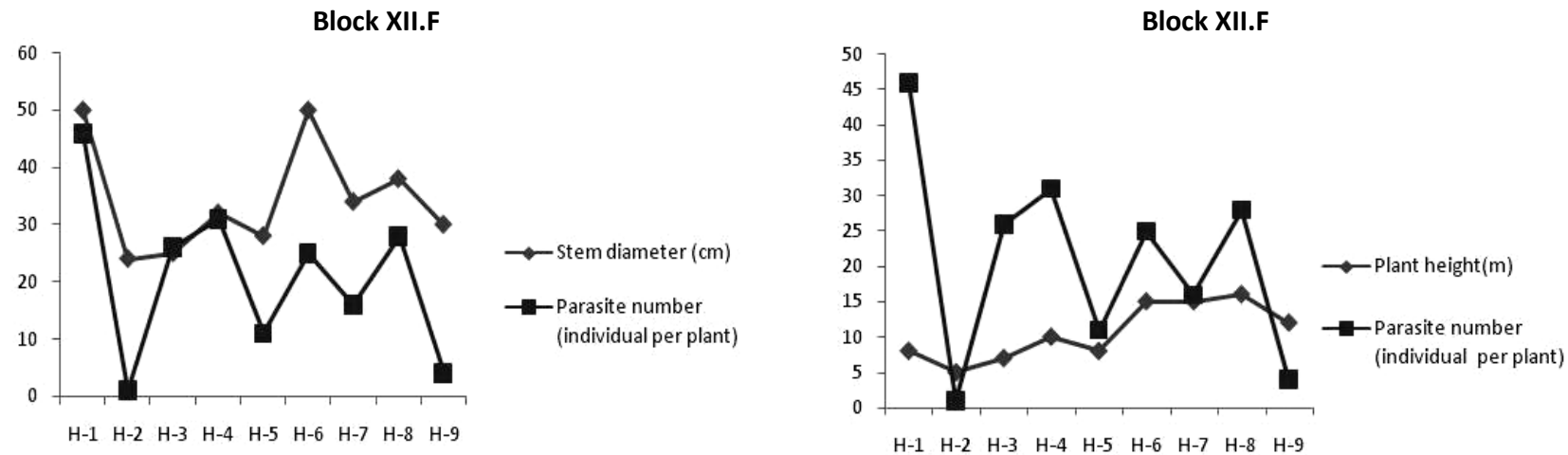

Host
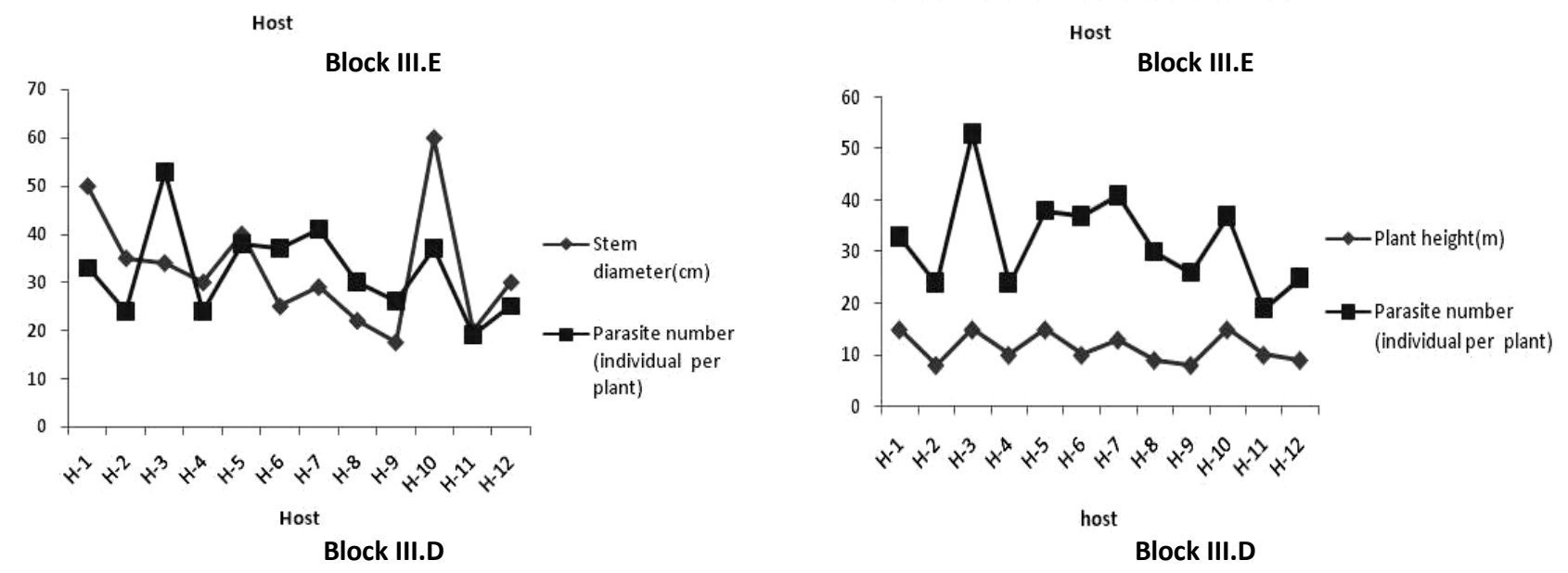

Figure 6. The parasite number on diameter and plant height of each host (Cassia fistula) in blocks XII.F, III.E, and III.D

\section{ACKNOWLEDGEMENTS}

The author thanks all staff of the Subsection of Exploration and Collection, Purwodadi Botanic Garden, Research Center for Plant Conservation and Botanic Garden, Indonesian Institute of Sciences who helped during the research.

\section{REFERENCES}

Ameer OZ, Salman IM, Quek KJ, Asmawi MZ. 2015. Loranthus ferrugineus: A mistletoe from traditional uses to laboratory bench. J Pharmacopunct 18 (1): 7-18. DOI: 10.3831/KPI.2015.18.001

Aukema JE, Martínez del Río C. 2002. Where does a fruit-eating bird deposit mistletoe seeds? Seed deposition patterns and an experiment.
Ecology $\quad 83 \quad$ (12): $\quad 489-496 . \quad$ DOI: $\quad 10.1890 / 0012-$ 9658(2002)083[3489:WDAFEB]2.0.CO;2

Backer CA, van den Brink B. 1965. Flora of Java Vol. II. NVP Noordhoff, Groningen, Netherland.

Barlow BA. 1997. Loranthaceae. Flora Malesiana. In: Kalkman C, DW Kirkup, HP Noteboom, PF Steven, WJJO de Wilde (eds) Seed Plants I (13): 209-401. Rijksherbarium/Hortus Botanicus, Leiden, Netherland.

Bediako AAE, Quaye AAA, Tetteh JP, Buah N, van der Puije GC, Acheampong RA. 2013. Prevalence of mistletoe on citrus trees in the Abura-Asebu-Kwamankese District of the central region of Ghana. Intl J Sci Tech Res 2 (7): 122-127.

Dlama TT, Oluwagbemileke AS, Enehezeyi AR. 2016. Mistletoe presence on five tree species of Samaru area, Nigeria. Afr J Plant Sci 10 (1): 16-22. DOI: $10.5897 / \mathrm{AJPS} 2015.1335$

Griebel A, Watson D, Pendall E. 2017. Mistletoe, friend and foe: synthesizing ecosystem Implications of mistletoe infection. Environ Res Lett 12 (2017): 1150121. DOI:10.1088/1748-9326/aa8fff.

Hardiyanti R, Marpaung L, Adyana IK, Simanjuntak P. 2018. Antioxidant and antibacterial activity of various extract of 'duku's mistletoe 
(Dendrophtoe pentandra (L.) Miq.) leaves extracts. Asian J Pharmaceut Clin Res 11 (12): 526-529. DOI 10.22159/ajpcr.2018.v11i12.29725

Kolodziejek J, Patykowski J, Kolodziejek R. 2013. Distribution frequency and host patterns of European mistletoe (Viscum album subsp. album) in the major city of Lodz. Poland Biol 68 (1): 55-64. DOI: 10.2478/s11756-012-0128-4.

Lech P, Zolciak A, Hildebrand R. 2020. Occurrence of European mistletoe (Viscum album L.) on forest trees in Poland and its dynamics of spread in the period 2008-2018. Forests 11 (83): 2-16. DOI 10.3390/f11010083.

Lim YC, Rajabalaya R, Lee SHF, Tennakoon KU, Le QV, Idris A, Zulkipli IN, Keasberry N, David SR. 2016. Parasitic mistletoes of the genera Scurrula and Viscum: from bench to bedside. Molecules 21 (1048): 2-34. DOI: 10.3390/molecules21081048

Luo Y, Sui Y, Gan J, Zhang L. 2016. Host compatibility interacts with seed dispersal to determine small-scale distribution of mistletoe in Xishuangbanna, southwest China. J Plant Ecol 9 (1): 77-86. DOI: 10.1093/jpe/rtv024.

Matula R, Svátek M, Pálková M, Volařík D, Vrška T. 2015. Mistletoe infection in an oak forest is influenced by competition and host size. PLoS ONE 10 (5): e0127055. DOI:10.1371/journal.pone.0127055.

Mellado A, Morillas L,Gallardo A, Zamora R. 2016. Temporal dynamic of parasite-mediated linkages between the forest canopy and soil processes and the microbial community. New Phytol 211 (4): 1382 1392. DOI: $10.1111 / \mathrm{nph} .13984$.

Miller IF, Creas IS, Nunn CL, Muehlenbein MP. 2018. Estimating infection prevalence: Best practices and their theoretical underpinnings. Ecol Evol 8 (8): 6738-6747. DOI: 10.1002/ece3.4179.

Monica E, Bolanos Q, Gonzalez EJ, Martorell C, Santana ZC. 2017 Competition and facilitation determine dwarf mistletoe infection dynamics. J Ecol 105 (3): 775-785. DOI: 10.1111/1365-2745.12699.

Muttaqin Z, Budi SWR, Wasis B, Siregar IZ, Corryanti. 2016. Assessing intensity of mistletoe infestation in teak clonal seed orchard (CSO) Padangan, East Java. Proc Env Sci 33: 404-415. DOI 10.1016/j.proenv.2016.03.091.
Priyanto JA, Pujiyanto S, Rukm I. 2014. Flavonoids production capability test of tea mistletoe (Scurrula atropurpurea Bl.Dans) endophytic bacteria isolates. Jurnal Sains dan Matematika 22 (4): 89-96. [Indonesian]

Rahmad RB, Fordjouri FA, Asyrofi M, Rosely NF. 2014. Mistletoe abundance, distribution and their associations with trees along roadside in Penang, Malaysia. Trop Ecol 55 (2): 255-262.

Rubiales D, Jørgensen H, Henning S. 2011. Parasitic Plants. In: Encyclopedia of Life Sciences (ELS). John Wiley \& Sons, Ltd: Chichester. DOI:10.1002/9780470015902.a0021271

Solikin. 2014. Parasitic plants on medicinal plants: Study in Purwodadi Botanic Garden. Proc Int Sem: Forest and Medicinal Plants for Better Human Welfare. Centre for Forest Productivity Research and Development, Bogor.

Solikin. 2016. Population dynamic of Viscum articulatum Burm.f. on its host in Purwodadi Botanic Garden. J Biol Res 21 (2): 81-84.

Solikin. 2017. Diversity of parasitic plants and their hosts in Kepala Jeri and Pemping agroforestry Batam Indonesia. J Biol Res 23 (1): 45-52. DOI:10.23869/bphjbr.23.1.20178

Solikin. 2020a. Parasitization of parasitic plants on fruit plants in Bangkalan Regency and Malang City, Indonesia. Eco Env Cons 26: 27-35.

Solikin. 2020b. Infestation of mistletoe Dendrophthoe pentandra (L.) Miq. on various canopy shading and plant diversity in Purwodadi Botanic Garden: A study on medicinal plant Cassia fistula L. J Biol Res 26 (1): 1-5. DOI: 10.23869/bphjbr.26.1.20201

Teodoro GS, van den Berg E, Arruda R. 2013. Metapopulation dynamics of the mistletoe and its host in savanna areas with different fire occurrence. PloS ONE 8 (6): e65836. DOI: 10.1371/journal.pone.0065836

Watson DM, Milner KV, Leigh A. 2017. Novel application of species richness estimators to predict the host range of parasites. Int $\mathbf{J}$ Parasitol 47 (1): 31-39. DOI: 10.1016/j.ijpara.2016.10.001.

Watson DM. 2016. Fleshing out facilitation reframing interaction networks beyond top-down versus bottom-up. New Phytol 211 (3): 803-808. DOI: $10.1111 /$ nph.14052 